\title{
Mutations in Wheat Exhibiting Growth-Stage-Specific Resistance to Biotrophic Fungal Pathogens
}

\author{
Phil H. Smith, ${ }^{1}$ John A. Howie, ${ }^{2}$ Anthony J. Worland, ${ }^{1}$ Rebecca Stratford, ${ }^{2}$ and Lesley A. Boyd ${ }^{1}$ \\ ${ }^{1}$ Department of Disease and Stress Biology, John Innes Centre, Colney Lane, Norwich Research Park, Norwich, NR4 7UH, \\ U.K.; ${ }^{2}$ Monsanto UK Ltd., The Maris Centre, Hauxton Road, Trumpington, Cambridge, CB2 2LQ, U.K.
}

Submitted 20 March 2004. Accepted 8 June 2004.

Two mutants were isolated in wheat that showed enhanced resistance towards Puccinia striiformis f. sp. tritici, the fungal causal agent of yellow rust. The altered phenotype of I3-48 is due to a minimum of two mutation events, each showing a partial, additive effect, with one mutation segregating with a deletion on the long arm of chromosome 4D. In the case of $\mathbf{I 3 - 5 4}$, the enhanced resistance is due to a single, dominant mutation. In both mutants, the expression of the enhanced resistance is growth-stage specific. With I354, the full resistance phenotype is apparent from the third seedling leaf onwards, while with I3-48, a full resistance phenotype is only seen on the tenth and subsequent leaves. In addition to the enhanced resistance towards yellow rust, I3-48 also shows enhanced resistance towards brown rust, and I3-54 shows enhanced resistance to powdery mildew.

Additional keywords: disease resistance, suppressor genes.

Disease resistance in wheat (Triticum aestivum, $2 n=6 x=$ 42) can be expressed at all growth stages, seedling resistance, or specifically at later stages of development, adult plant (APR) or field resistance. Seedling resistance to biotrophic fungal pathogens is generally race-specific, while APR is often partial and non-race-specific (Bariana and McIntosh 1995; Worland and Law 1992). In addition to resistance genes that inhibit pathogen invasion and disease establishment, genes have been identified that appear to enhance the establishment of infection (Assefa and Fehrmann 2000; Kema et al. 1995; Ma et al. 1995; Vogel et al. 2002). These genes have been termed "suppressor" or "susceptibility" genes, and examples have been reported that act specifically against designated seedling resistance genes (Kerber and Aung 1995, 1999; Nelson et al. 1997) as well as more generally against APR (Pink et al. 1983; Worland and Law 1992). The interaction between genes conferring resistance and genes that modify the degree of resistance adds another level of complexity to the host-pathogen interaction.

The transfer of rust resistance genes from diploid wheat into a hexaploid background has often resulted in the loss of the resistance phenotype (Assefa and Fehrmann 2000; Kema et al. 1995; Ma et al. 1995). Specific suppressors of stem rust resistance genes have been identified in the cultivar Canthatch on chromosome 7DL (Kerber and Aung 1995, 1999) and, for Lr23, on the 2DS chromosome from Aegilops tauschii (Nelson

Corresponding author: Lesley A. Boyd; E-mail: lesley.boyd@bbsrc.ac.uk; Telephone: +44 1603 450614; Fax: +44 1603450045 .

A. J. Worland passed away on April 23, 2001. et al. 1997). Chromosomes that specifically compromise APR to yellow rust have also been identified in hexaploid wheat (Worland and Law 1992). Chromosomes of homologous group 5 carry opposing genes for promotion of resistance on their short arms and for promotion of susceptibility on their long arms (Pink et al. 1983). In the wheat line Hobbit 'sib' chromosomes $1 \mathrm{~A}, 2 \mathrm{~A}, 4 \mathrm{~A}, 2 \mathrm{~B}, 5 \mathrm{BS}-7 \mathrm{BS}, 6 \mathrm{~B}$ and $2 \mathrm{D}$ contribute to APR, whereas chromosomes 3B, 4B, 5BL-7BL, 4D and 5D increase levels of yellow rust infection (Worland and Law 1992).

Cosegregation of resistance towards different pathogens has been reported for both seedling and APR (McIntosh and Arts 1996; Singh 1993). In wheat, cosegregation of APR to yellow rust and brown rust is common (Singh et al. 2001). Likewise, for chromosomes conferring suppressor effects, cosegregation of susceptibility to the biotrophic fungal pathogens causing yellow rust and powdery mildew was found for the group 5 chromosomes (Pink et al. 1983).

Mutants showing increased resistance to biotrophic fungal pathogens have been isolated in other cereals, including barley (Jorgensen 1992), maize (Simmons et al. 1998), and rice (Takahashi et al. 1999; Zeng et al. 2002). In those cases in which the gene has been isolated, it appears to play a role in downregulating programmed cell death (Gray et al. 1997; Piffanelli et al. 2002). In Arabidopsis, mutants showing increased disease resistance but with no associated lesion phenotype appear to be involved in cellular processes ranging from cation signaling (Clough et al. 2000) to cell wall structure (Vogel et al. 2002).

Hexaploid wheat provides a unique system in which to study the interaction between genes conferring resistance and the genes responsible for the control of resistance responses. Although genetically a diploid, the three genomes of T. aestivum provide a buffering system that allows the isolation of mutants that in a diploid may be lethal and, therefore, never observed. To locate and evaluate genes that modify resistance to yellow rust in the wheat line Hobbit 'sib,' a mutagenized population was created by fast neutron bombardment. Mutant lines were initially selected that showed enhanced field resistance to yellow rust. These lines were subsequently tested to determine the growth stage at which the enhanced resistance was expressed and for resistance to other biotrophic fungal pathogens. In this paper, we report on the characterization of two of these mutants.

\section{RESULTS}

Adult plant disease resistance testing.

Two mutant lines selected for enhanced yellow rust resistance from the M2 through to the M7 generation, I3-48 and I354 , were tested in subsequent generations for yellow rust, 
brown rust, and powdery mildew resistance under either field, greenhouse, or both conditions, as adult plants. In both field and greenhouse adult plant tests, significantly less yellow rust infection was seen on both the selected lines, as compared with Hobbit 'sib', when inoculated with the single Puccinia striiformis f. sp. tritici isolate WYR 79/4 or with a mixture of $P$. striiformis f. sp. tritici isolates (Table 1). Slightly lower levels of yellow rust infection were seen in the greenhouse tests compared with that seen in the field tests, but the differences were not significant.

Hobbit 'sib' and both mutants were screened for resistance to brown rust in field tests. I3-48 showed resistance to brown rust, being significantly different from Hobbit 'sib' at a least significant difference $(\mathrm{LSD})=1 \%$ (Table 1 ); however, I3-54 did not differ from Hobbit 'sib' for brown rust resistance. Powdery mildew infection was scored on adult plants under greenhouse conditions. I3-48 did not differ from Hobbit 'sib', but I3-54 supported far less powdery mildew infection (Table 1). Therefore, while the parental line appeared moderately susceptible to all three fungal pathogens tested, mutant I3-48 was resistant to yellow rust and brown rust, whereas mutant I3-54 was resistant to yellow rust and powdery mildew.

\section{Seedling yellow rust resistance testing.}

As the mutants were selected for enhanced resistance to yellow rust as adult plants, we asked whether the phenotype expressed at earlier growth stages. Plants up to the tenth leaf stage were inoculated with three different $P$. striiformis f. sp. tritici isolates, and the extent of yellow rust development on the third to the ninth leaves was measured in two separate tests.

In test 1 , the percentage of sporulation was measured on the third, fourth, and fifth leaves 14 days after inoculation (dai). No significant differences were found between isolates. There were significantly more sporulating colonies on the fifth leaf of Hobbit 'sib' compared with the older third and fourth leaves. This probably reflects the ability of younger, healthier leaves to support the growth of a biotrophic fungus. Fewer sporulating colonies were produced on I3-48 as compared with Hobbit 'sib.' at all leaf ages sampled, but the differences were only significant at a $p<0.01$. I3-48 produced approximately one quarter of the number of sporulating colonies seen on Hobbit 'sib.' With I3-54, no sporulating colonies were produced by any of the $P$. striiformis f. sp. tritici isolates.

Spores were collected off the fifth leaf of Hobbit 'sib,' I3-48, and I3-54. There were no significant differences between isolates for spore counts. I3-48 produced between 100 to 200 spores per square centimeter of inoculated leaf tissue, approximately one quarter the number of spores produced on Hobbit 'sib.' No spores were produced on I3-54.

In test 2 , for both colony number and percent sporulation, no significant differences were seen between the three yellow rust isolates. When comparing within a wheat line, there were significantly fewer colonies and less sporulation on the sixth and seventh leaves of Hobbit 'sib' and fewer colonies on the sixth leaf of the mutants as compared with the later, younger leaves (Fig. 1). This again reflects the ability of younger, healthier leaves to support the growth of a biotrophic fungus.

At all leaf ages sampled, similar numbers of colonies were seen on I3-48 and I3-54 but significantly less than on Hobbit 'sib.' In general, the two mutants supported between 20 to $60 \%$ of the colony growth seen on Hobbit 'sib' (Fig. 1). However, the number of sporulating colonies on I3-48 and I3-54 were 25 and $6 \%$, respectively, of that seen on Hobbit 'sib,' averaged across all leaf ages and isolates (Fig. 1).

Isolate WYR79/4 produced significantly more spores on Hobbit 'sib' on both the eighth and ninth leaves and on the younger ninth leaf of I3-48 and I3-54, compared with the other isolates (Fig. 1). However, for all three isolates, the two mutants produced far fewer spores per square centimeter of inoculated leaf than the parental line Hobbit 'sib.'

Although I3-48 and I3-54 supported similar levels of colony formation on leaves of the same age, I3-54 produced fewer sporulating colonies and fewer spores than I3-48. With I3-48, less yellow rust infection was seen on all leaf ages tested, but the full resistance response expressed by I3-48 was not seen until the tenth leaf (Fig. 2). The full yellow rust resistance response of 13-54, however, was observed from the third leaf onwards. This would suggest that the mutations affecting the resistance in I3-48 and I3-54 are different, the enhanced resistance in I3-54 expressing at an earlier growth stage.

\section{Genetic analysis}

of the mutation-derived yellow rust resistance phenotypes.

Segregation of yellow rust resistance in the I3-48 $\times$ Hobbit 'sib' cross appeared to involve at least two independently segregating mutation events. The $\mathrm{F}_{2}$ population (154 field-tested $\mathrm{F}_{2}$ plants) gave a continuous distribution of yellow rust infection levels, from which 10 susceptible $F_{2}$ plants produced only susceptible $F_{3}$ families. Grouping the remaining $F_{2}$ plants into one resistance class ( $144 \mathrm{~F}_{2}$ plants), the data did not differ significantly from a 15R: $1 \mathrm{~S}$ expected ratio $\left(\chi^{2}=0.016, \mathrm{df}=1, p\right.$ $>0.90)$, indicating that at least two independent mutation events were contributing to the enhanced yellow rust resistance in I3-48. In I3-54, a single dominant mutation was responsible for the enhanced yellow rust resistance. From $232 \mathrm{~F}_{2} / \mathrm{F}_{3}$ fieldtested families of the I3-54 $\times$ Hobbit 'sib' cross, 51 were yellow rust susceptible, giving a reasonable fit to a $3 \mathrm{R}: 1 \mathrm{~S}$ expected ratio for a single, dominant gene $\left(\chi^{2}=1.12\right.$, $\mathrm{df}=1, p>$ $0.25)$.

\section{Molecular analysis}

of the mutation-derived yellow rust resistance phenotypes.

As, in early $M$ generations, seed had been collected from field-grown plants, the molecular uniformity of the mutant lines compared with Hobbit 'sib' was assessed using simple sequence repeat (SSR) markers. SSR markers were screened on the M11 generation collected from the M10 plants used in

Table 1. Levels of disease on adult plants in field and greenhouse tests ${ }^{\mathrm{a}}$

\begin{tabular}{|c|c|c|c|c|c|c|}
\hline \multirow[b]{2}{*}{ Wheat Line } & \multicolumn{3}{|c|}{ Yellow rust } & \multicolumn{2}{|c|}{ Brown rust } & \multirow{2}{*}{$\begin{array}{c}\text { Powdery mildew } \\
\text { Greenhouse } \\
\text { JIW14 }\end{array}$} \\
\hline & $\begin{array}{c}\text { Field }^{b} \\
\text { WYR79/4 }^{2}\end{array}$ & $\begin{array}{c}\text { Field }^{\mathbf{c}} \\
\text { Isolate Mix }\end{array}$ & $\begin{array}{l}\text { Greenhouse } \\
\text { Isolate Mix }\end{array}$ & $\begin{array}{c}\text { Field }^{\mathrm{c}} \\
\text { WBR90/12 WBR90/25 }\end{array}$ & $\begin{array}{c}\text { Field }^{\mathrm{c}} \\
\text { Isolate Mix }\end{array}$ & \\
\hline Hobbit 'sib' & 50 & $50 \mathrm{MS}$ & $40 \mathrm{MS}$ & $50 \mathrm{~S}$ & $80 \mathrm{~S}$ & 70 \\
\hline I3-48 & 5 & $10 \mathrm{R}$ & $0 \mathrm{R}$ & $20 \mathrm{MR}$ & $10 \mathrm{MR}$ & 60 \\
\hline I3-54 & 10 & $10 \mathrm{R}$ & 0 to $5 \mathrm{R}$ & $60 \mathrm{~S}$ & $50 \mathrm{~S}$ & 10 \\
\hline
\end{tabular}

${ }^{a}$ The percentage of yellow rust, brown rust, and powdery mildew infection on adult plants under field and greenhouse conditions. The extent of necrosis and chlorosis associated with infection was scored as follows. $\mathrm{R}=$ resistant, $\mathrm{MR}=$ moderately resistant, $\mathrm{MS}=$ moderately susceptible, or $\mathrm{S}=$ susceptible.

${ }^{\mathrm{b}}$ Percentage of infections are an average of three years of tests.

${ }^{\mathrm{c}}$ Percentage of infections are an average of two years of tests. 
the greenhouse yellow rust adult plant test. A total of $50 \mathrm{SSR}$ markers, with at least one marker for each chromosome arm, were screened. No variation within lines or between Hobbit 'sib' and the two mutants was detected (data not shown).

Backcrossing of I3-48 and I3-54 to a complete, monosomic series of Hobbit 'sib' identified chromosome 4D of I3-48 and $4 \mathrm{~B}$ of I3-54 as contributing to the yellow rust resistance phenotypes (data not shown). Chromosomes 4B and 4D had

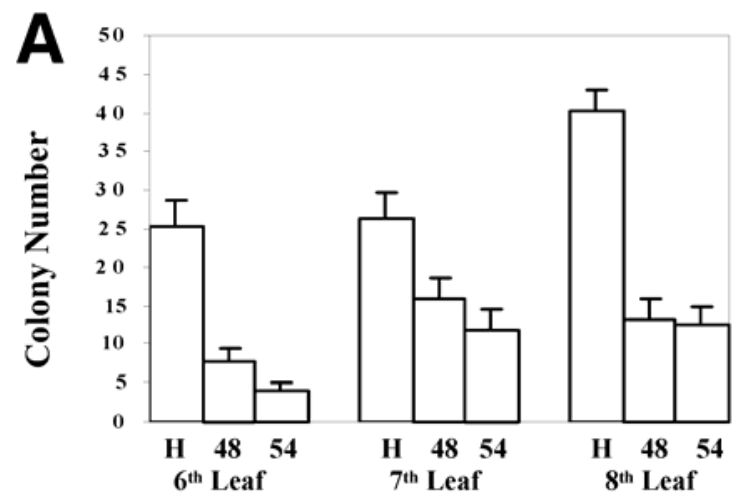

Wheat Line by Leaf Age

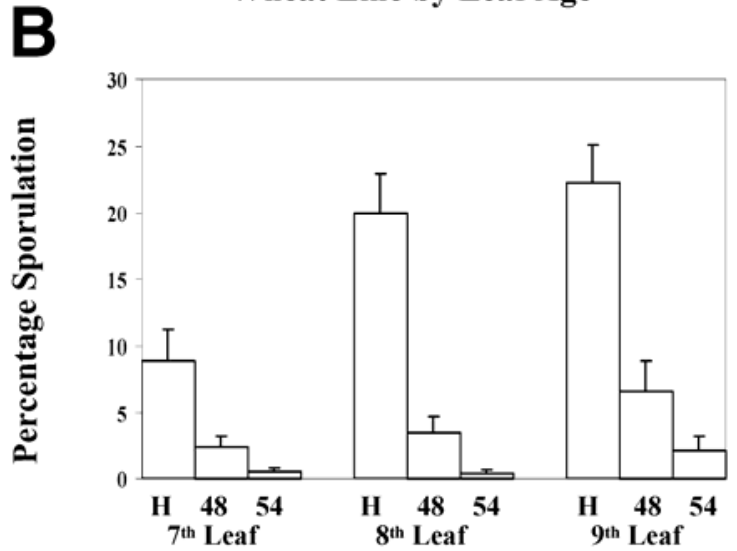

Wheat Line by Leaf Age

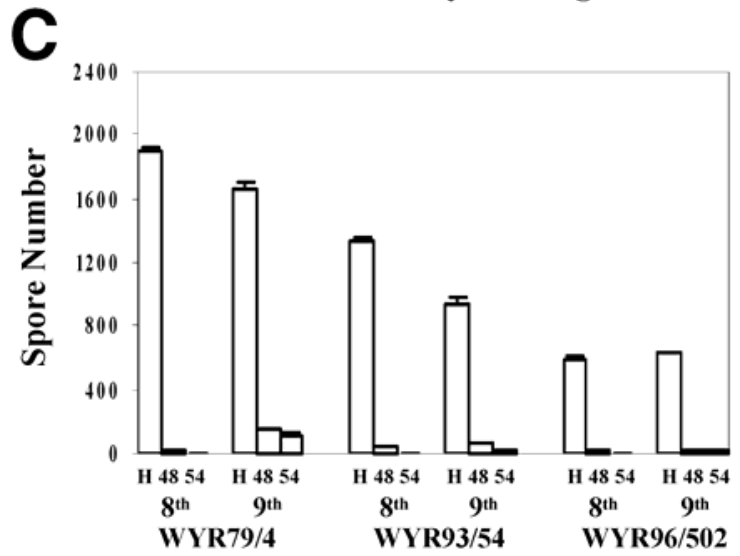

Wheat Line by Leaf Age and Isolate

Fig. 1. Yellow rust seedling tests. A, Mean colony number per square centimeter of inoculated seedling leaf for the sixth, seventh, and eighth leaves, averaged over three Puccinia striiformis f. sp. tritici isolates. B, Mean percentage sporulation per square centimeter of inoculated seedling leaf for the seventh, eighth, and ninth leaves averaged over three $P$. striiformis f. sp. tritici isolates. C, Mean spore production per square centimeter of inoculated seedling leaf for the eighth and ninth leaves for three $P$. striiformis f. sp. tritici isolates, WYR79/4, WYR93/54, and WYR96/502. Lines shown are Hobbit 'sib' $(\mathrm{H})$ and mutants I3-48 (48) and I3-54 (54). Bars indicate standard errors. already been identified as having a suppressor effect on yellow rust resistance in Hobbit 'sib' (Worland and Law 1992) along with chromosomes 3B, 5BL-7BL, and 5D. These chromosomes were therefore targeted as possible sites of the mutations responsible for the enhanced yellow rust resistance seen in I3-48 and I3-54.

As these mutant lines were generated by fast neutron bombardment, it was considered that the mutant phenotypes may be the result of chromosomal deletions. To identify deletions, genomic DNA was probed with restriction fragment length polymorphism (RFLP) markers that had been mapped in the Chinese Spring $\times$ Synthetic Wheat mapping population (Howie 1997). In I3-48, a deletion was located on the long arm of chromosome 4D (Fig. 3), spanning a maximum region of 18 centiMorgan $(\mathrm{cM})$ and flanked by markers PSR1318 $(4 \mathrm{cM})$ and PSR484 (22 cM) (Gale et al. 1993). However, no deletions were detected in I3-54 using RFLP markers; therefore, a more directed approach was taken to isolate genomic DNA fragments present in Hobbit 'sib' but absent from I3-54. Using a subtractive hybridization procedure, representational difference analysis (RDA), 17 nonrepetitive RDA clones were isolated, using I3-54 as the driver genotype. Five of these clones

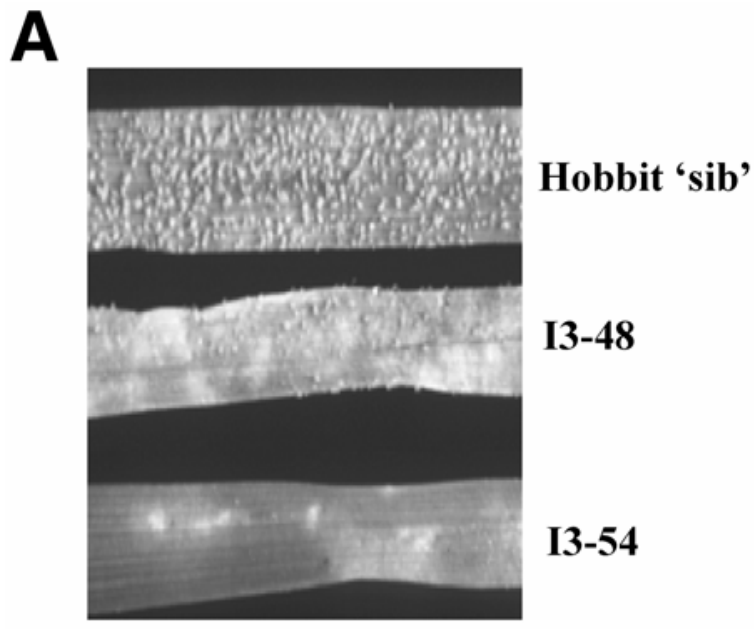

Seedling $-7^{\text {th }}$ Leaf

B

I3-48

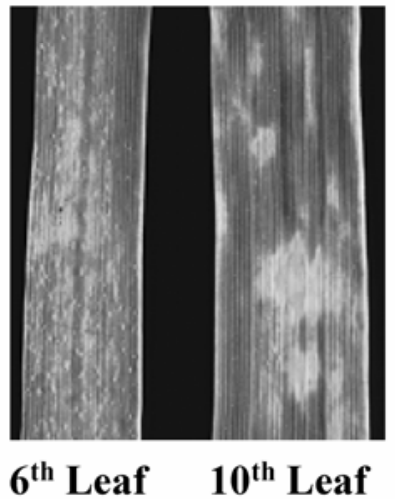

Fig. 2. Yellow rust seedling infections. A, The seventh seedling leaf of Hobbit 'sib', I3-48, and I3-54 14 days after inoculation (dai) with Puccinia striiformis $\mathrm{f}$. sp. tritici isolate WYR96/502. B, The sixth and tenth seedling leaves off the same I3-48 plant 14 dai with $P$. striiformis f. sp. tritici isolate WYR96/502. 
identified deletions in I3-54 (Table 2), although two clones (RDA 4 and 18) had the same banding pattern, suggesting that they could be identical clones. Nullisomic and nulli-tetrasomic analysis placed all the RDA clones on chromosome 7A.

\section{Segregation of deletions}

with mutation-derived yellow rust resistance phenotype.

The deletion on chromosome 4D in I3-48 was shown to cosegregate with the enhanced yellow rust resistance. A total of $72 \mathrm{~F}_{2}$ seedlings from the I3-48 $\times$ Hobbit 'sib' cross tested for their yellow rust resistance response at the ninth-leaf seedling-growth stage were grouped into four classes, based on the level of yellow rust infection on the seventh and eighth leaves. Twelve $\mathrm{F}_{2}$ plants supported less than $5 \%$ yellow rust infection (resistant), whereas 11 plants supported over $70 \%$ infection (susceptible). However, 25 and $24 \mathrm{~F}_{2}$ plants, respectively, fell into two intermediate groups, intermediate resistant plants showing between 10 to $30 \%$ infection and intermediate susceptible plants supporting between 40 to $60 \%$ infection.

Individual plants were screened for the presence of the deletion on the long arm of chromosome 4D. RFLP markers PSR104 and PSR163, lying approximately $2.5 \mathrm{cM}$ apart (Fig. 3 ), were used to identify the deletion. Only $F_{2}$ plants homozygous for the 4DL deletion could be identified, heterozygotes being indistinguishable from wild-type homozygotes. All $12 \mathrm{~F}_{2}$ plants in the resistant group were homozygous for the 4DL deletion. In the intermediate resistant group, 12 plants (approximately 50\%) were also homozygous for the deletion. No plants in the intermediate susceptible or susceptible groups were homozygous for the deletion on 4DL. The deletion on 4DL, therefore, appeared to contribute significantly to the enhanced yellow rust resistance.

Although monosomic analysis implicated chromosome 4B in I3-54 as contributing to the enhanced yellow rust resistance, the inability to detect a deletion on this chromosome meant that an association between chromosome $4 \mathrm{~B}$ and the yellow rust resistance could not be tested in the I3-54 $\times$ Hobbit 'sib' cross. The deletion detected on chromosome 7A in I3-54 was tested but segregated independently of the enhanced yellow rust resistance. Of the $56 \mathrm{~F}_{2}$ seedlings from the I3-54 $\times$ Hobbit 'sib' cross, 43 were resistant to yellow rust and 13 were susceptible.

\section{DISCUSSION}

Through mutation, two wheat variants were isolated that show enhanced resistance to the fungal pathogen $P$. striiformis f. sp. tritici, the causal agent of yellow rust. The overall morphology of the mutants did not differ from that of Hobbit 'sib,' despite the presence of chromosomal deletions in each mutant. The gain-of-function phenotypes in I3-48 and I3-54 would suggest that i) systems involved in regulating plant resistance have been disrupted, resulting in an enhancement of resistance responses or ii) that alterations in the plant's cells and tissues have made it no longer able to provide the compatible environment required by the pathogen.

The continuous distribution of yellow rust infection seen in the I3-48 $\times$ Hobbit 'sib' $\mathrm{F}_{2} / \mathrm{F}_{3}$ population would indicate a partial, additive effect of each mutant "allele." A gene dosage effect between resistance and suppressor genes was reported in the oat crown rust system (Wilson and McMullen 1997). The crown rust resistance gene $P c 38$ is closely linked to a gene (Pc38-S complex) that specifically suppresses resistance expressed by the gene Pc62. Pc62 resistance is expressed in the presence of one copy of the Pc38-S complex, but not in a trisomic, containing two copies of $P c 38-\mathrm{S}$, while increasing the copies of $P c 62$ relative to $P c 38-\mathrm{S}$ restores expression of the $P c 62$ resistance.
The dominant gain-of-function phenotype seen in I3-54 would suggest the system operating in I3-54 is different from that in I3-48. No deletion could be found associated with the enhanced yellow rust resistance in I3-54, implying a possible small mutational event (i.e., a small deletion or point mutation) may be responsible for the altered phenotype. The mutation may therefore involve an alteration in a gene that is still expressed but altered in such a way that the gene product now confers an enhancer effect, increasing resistance and conferring a dominant phenotype.

Mutations have been identified in other cereals that show enhanced resistance to biotrophic fungal pathogens (Jorgensen 1992; Simmons et al. 1998; Zeng et al. 2002). The classic example is the mlo mutation in barley that confers non-race-specific resistance to powdery mildew. This mutation is recessive and results in a more rapid and larger papilla response towards attempted penetration by the fungus (Jorgensen 1992). In maize, the recessive $l l s l$ mutant is able to retard germination and growth, producing fewer and smaller colonies of the rust pathogen Puccinia sorghi (Simmons et al. 1998). In rice, the spl11 recessive lesion mimic mutant confers non-race-specific resistance to the fungal pathogen Magnaporthe grisea and the bacterial pathogen Xanthomonas oryzae pv. oryzae (Zeng et al. 2002), while the dominant mutant $C d r 3$ confers resistance to M. grisea (Takahashi et al. 1999).

All these mutants are associated with the formation of spontaneous lesions, and the wild-type genes are thought to function by down-regulating programmed cell death (Gray et al. 1997; Piffanelli et al. 2002). However, no spontaneous lesion phenotype is seen in I3-48 and I3-54. Therefore, the enhanced resistance in these wheat mutants may be due to disruption of

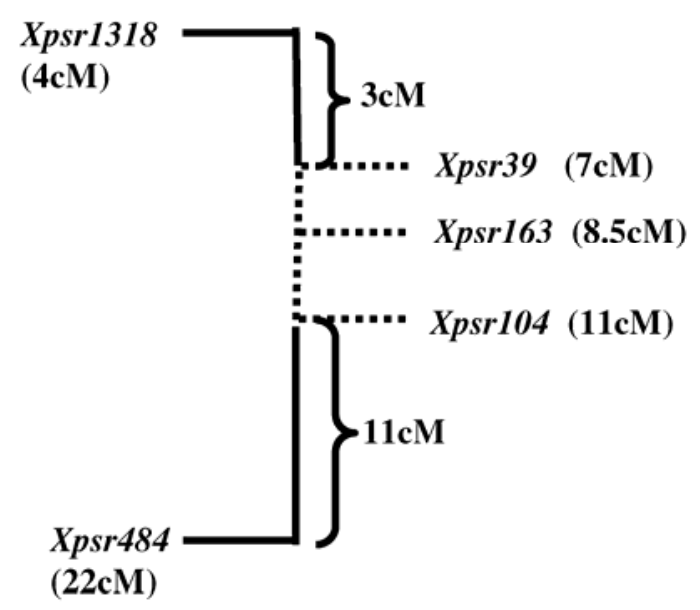

\section{Chromosome 4DL}

Fig. 3. Location of the deletion on the long arm of chromosome 4D in I348. The deleted restriction fragment length polymorphism markers are indicated by broken lines. The distances of the markers are given in centiMorgans (cM) from the centromere (Gale et al. 1993).

Table 2. I3-54 deletion-specific clones isolated from Hobbit 'sib' using representational difference analysis (RDA)

\begin{tabular}{lccc}
\hline $\begin{array}{l}\text { Clone } \\
\text { number }\end{array}$ & $\begin{array}{c}\text { Clone } \\
\text { size (bp) }\end{array}$ & $\begin{array}{c}\text { Size of deleted band (kb) } \\
\text { (restriction enzyme) }\end{array}$ & $\begin{array}{c}\text { Chromosomal location } \\
\text { of RDA clone }\end{array}$ \\
\hline RDA9 & 450 & $9.3($ DraI $)$ & $7 \mathrm{~A}$ \\
RDA4/18 & 450 & $9.3($ DraI $)$ & $7 \mathrm{~A}$ \\
RDA22 & 680 & $7.7($ DraI $)$ & $7 \mathrm{~A}$ \\
RDA23 & 580 & $4.4($ EcoRV $)$ & $7 \mathrm{~A}$ \\
\hline
\end{tabular}

a The restriction enzyme used to cut the genomic DNA is shown in brackets. 
resistance responses other than those leading to cell death or may be mutations in gene products that alter the cellular environment of the plant, thereby preventing the establishment of a compatible biotrophic interaction.

Mutants have been identified in Arabidopsis that show enhanced resistance to a broad spectrum of pathogens but which do not show a spontaneous lesion-mimic phenotype. These include the recessive $d n d 1$ mutant, which encodes for a cyclic nucleotide-gated ion channel (Clough et al. 2000) and may, therefore, be disrupted in signaling pathways regulating resistance responses and the pmr6 mutation, which encodes a pectate lyase-like protein, mutation in which has altered the composition of the plant cell wall (Vogel et al. 2002). The mutations in I3-48 and I3-54 could therefore represent a number of possible scenarios, ranging from disruption in signaling pathways controlling resistance responses to alterations in cell components that restrict fungal growth.

The yellow rust resistance exhibited by I3-48 and I3-54 was maintained against a range of isolates with very different virulence profiles. This would suggest a broad-spectrum resistance similar to that shown by the mlo mutant in barley (Jorgensen 1992). However, more extensive testing is required before excluding the possibility of a race-specific interaction between $P$. striiformis f. sp. tritici and the mutations in I3-48 and I3-54.

In addition to yellow rust resistance, I3-48 showed resistance to brown rust, and I3-54 showed resistance to powdery mildew. This multiple pathogen resistance has been seen in other wheat mutants (Boyd and Minchin 2001; Boyd et al. 2002), rice (Zeng et al. 2002), maize (Simmons et al. 1998), and in Arabidopsis (Aarts et al. 1998). This multiple pathogen resistance may represent mutations in genes and pathways common to more than one pathogen or additional mutations in I3-48 and I3-54 may be responsible for the resistance to brown rust and powdery mildew, respectively. Mapping of the mutations conferring resistance to each pathogen will help determine whether the resistance to multiple pathogens is pleiotropic or represents independent mutation events.

As I3-48 and I3-54 were originally selected for enhanced resistance to yellow rust as adult plants, greenhouse tests were carried out on younger plants, to determine at which growth stage the mutant phenotype expressed. In I3-48, a level of yellow rust resistance comparable to that seen on adult plants was not observed until the tenth seedling leaf, whereas for I3-54, full resistance towards $P$. striiformis f. sp. tritici was clear from the third seedling leaf onwards. Developmentally regulated expression of resistance has been identified in many crop species, including wheat (Bariana and McIntosh 1995) and rice (Century et al. 1999). In rice, resistance conferred by Xa21 progressively increases as the plant develops. At the secondleaf stage $X a 21$ rice plants are susceptible to $X$. oryzae pv. oryzae but by the ninth- or tenth-leaf show complete resistance. However, this developmentally regulated expression of resistance was not dependent on transcription of $\mathrm{Xa21}$.

Although fewer colonies were produced on both I3-48 and I3-54 compared with that on Hobbit 'sib' at all comparable leaf ages, the mutations did not appear to totally prevent growth of $P$. striiformis f. sp. tritici hyphae. However, the production of spores from these colony sites was substantially reduced in both mutants and was generally eliminated when full resistance was expressed. These initial observations suggest that, in both mutants, $P$. striiformis $\mathrm{f}$. sp. tritici infection is stopped at later stages in the pathogen's life cycle than is common in race-specific resistance (Garrood 2001). Further, detailed microscopic examination is underway to determine the fate of $P$. striiformis $\mathrm{f}$. sp. tritici development in each mutant line and may give an insight into the physiological changes in these mutants that are conferring the enhanced resistance.
Two genetically distinct wheat mutants are presented that appear to restrict development of the fungal pathogen $P$. striiformis $\mathrm{f}$. sp. tritici. The identification of genes that actively reduce the ability of wheat to resist disease has serious implications for optimizing disease resistance in commercial wheat cultivars. By identifying these genes, we should be able to select for variation, either allelic or via mutation, that expresses a weaker modifier effect. In this way, wheat breeders may be able to optimize the use of resistance genes, possibly simultaneously to multiple diseases, by selecting for weak or null "modifier" alleles.

\section{MATERIALS AND METHODS}

\section{Selection of wheat mutant lines showing enhanced yellow rust resistance.}

Dry seed of the wheat line Hobbit 'sib' was irradiated with fast neutrons (500 to 600 rads) at the International Atomic Energy Authority, Vienna, to give M1 generation seed. A total of 2,000 M1 seeds were sown at a field site near the Plant Breeding Institute, Cambridge, U.K. M1 plants were selfpollinated by covering spikes with cellophane bags. Eight M2 plants of each line were sown in rows in the following year and were inoculated with the $P$. striiformis f. sp. tritici isolate WYR79/4 (race 41E136), to which Hobbit 'sib' is susceptible at all growth stages. A total of 40 plants showing the lowest levels of yellow rust infection were selected. These consisted of two plants from 20 different M2 lines. Selfed progeny from each M2 plant were screened in field tests for yellow rust infection, up to the M6 generation, taking two plants from each selected family for subsequent testing. All selected M3 families were checked to determine their chromosome number. Six pairs of selections were discarded at this point, due to segregation of aneuploids. By the M7 generation, six lines had been selected as showing a consistent fixed phenotype, exhibiting enhanced yellow rust resistance. The analysis of two of these lines, I3-48 and I3-54, is presented here.

\section{Field tests for disease resistance.}

The M7 to M11 generations of the selected mutant lines were tested for yellow rust resistance in field tests in 1997 through 2001. Field sites near Norwich were used in each year. Tests were sown in the autumn and were scored for yellow rust infection in June or July of the following year. The field tests were set up in a replicated, randomized block design. Two replicates of 10 plant rows were sown in each year.

The M7 to M9 generations were inoculated with a single isolate of $P$. striiformis f. sp. tritici, WYR 79/4. Generations M10 and M11 were inoculated with the following mixture of isolates, representing genotypes present at high frequencies in the U.K. P. striiformis f. sp. tritici population during the years of testing (Bayles et al. 2001).

WYR 96/502, virulent on $\mathrm{Yr} 1,2,3,6,9$, and 17 , cultivars Madrigal and Equinox

WYR 93/54, virulent on $\operatorname{Yr} 1,2,3,4,6,9,13$, and 14 , cultivar Haven

WYR 93/24, virulent on $\operatorname{Yrl}, 2,3,4,6, C V, 13$, and 14 , cultivar Hereward

WYR 90/505, virulent on $Y r 1,2,3,4,7$, and 14 , cultivar Brock

WYR 95/12, virulent on $\operatorname{Yrl}, 2,3,4,9,13$, and 17 , cultivar Brigadier

P. striiformis f. sp. tritici isolates were inoculated onto seedlings of the susceptible spreader cultivar Kharchia Local and were transplanted into the field test site in March. Yellow rust disease scores were taken on three separate occasions, 10 to 14 
days apart, measuring the percentage of whole plant infected and the extent of chlorotic or necrotic tissue associated with developing pustules (McIntosh et al. 1995). $\mathrm{R}=$ pustules with few or no spores, surrounded by necrotic tissue; $M R=$ sporeproducing pustules surrounded by necrotic tissue; $\mathrm{MS}=$ sporeproducing pustules surrounded by chlorotic tissue; and $\mathrm{S}=$ spore-producing pustules surrounded by green tissue.

The M8 (1998) and M9 (1999) generations were tested in the field for brown rust resistance, using two $P$. triticina isolates, WBR 90/12 and WBR 90/25 (JIC Cereal Rust Collection), to which Hobbit 'sib' is susceptible at all growth stages. In 2000 and 2001, the M10 and M11 generations were inoculated with a mixture of brown rust isolates, including WBR 90/12, WBR 90/25, and WBR 93/1, plus an isolate then present at a high frequency in the U.K. $P$. triticina population (Bayles et al. 2001), WBR 98-20, which is virulent on Lr3a, $17 b$, and 26, cultivar Chablis.

The cultivar Armada was used as the brown rust susceptible spreader. The field tests were set up as two replicates of 10 plant rows. Brown rust infection scores were taken on two separate occasions 10 to 14 days apart in July, using the same scoring system as that used for yellow rust.

\section{Greenhouse tests for adult plant resistance.}

Hobbit 'sib' and mutants I3-48 and I3-54 were grown under disease-free conditions to growth stage 49-51 (early ear emergence) (Zadoks et al. 1974). The greenhouse tests were carried out on the M10 generation. For the yellow rust test, 10 plants of each line were inoculated with a mixture of $P$. striiformis $\mathrm{f}$. sp. tritici isolates WYR79/4, WYR 93/54, and WYR 96/502 in equal proportions and were screened for yellow rust infection 20 dai. Yellow rust inoculations were carried out as described by Boyd and Minchen (2001). Yellow rust infection was measured using the same scale used to score yellow rust on adult plants in field tests.

For the powdery mildew test, 10 plants of each line were inoculated with an isolate of Blumeria graminis f. sp. tritici (the causal agent of powdery mildew) from the JIC Cereal Powdery Mildew Collection, JIW14 (virulent on Pm4a, Pm5, Pm6, Pm7, and Pm17), to which Hobbit 'sib' is susceptible at all growth stages. The levels of powdery mildew infection were measured 20 dai as a percentage of the whole plant supporting sporulating colonies. Powdery mildew inoculations were carried out as described by Boyd and associates (1994).

\section{Greenhouse tests for seedling disease resistance.}

Two yellow rust seedling tests were carried out on Hobbit 'sib', I3-48, and I3-54 on the M10 generation. Each leaf was tagged as it emerged, the first leaf being designated one and so on. In test 1, 10 seedlings of each line were grown to the fifthleaf stage, so that the third, fourth, and fifth leaves were identifiable. In test 2, 10 seedlings were grown to the tenth leaf stage, so that the sixth, seventh, eighth, ninth, and tenth leaves were identifiable. The seedlings were inoculated with one of three different $P$. striiformis f. sp. tritici isolates, WYR 79/4, WYR 93/54, or WYR 96/502, as described by Boyd and Minchen (2001). On each seedling leaf, a 2-cm length of inoculated leaf was marked, and the following infection phenotypes were scored.

Colony number, the number of colonies formed per square centimeter of inoculated leaf tissue, was scored before sporulation, approximately 9 to 11 dai. A circular area of pale tissue within a green region of inoculated leaf was scored as a colony. One measurement was taken for each seedling leaf, covering a 2-cm length of leaf tissue. Colony numbers were only measured in test 2 , with counts being taken on the sixth, seventh, and eighth leaves.
Percent sporulation, the percentage of the inoculated leaf tissue producing sporulating colonies 14 dai was measured once for each seedling leaf, within the designated 2-cm length of inoculated leaf tissue. For test 1, percent sporulation was scored on the third, fourth, and fifth leaves. For test 2, percent sporulation was scored on the sixth, seventh, eighth, and ninth leaves.

Spore production, the number of spores produced per square centimeter of inoculated leaf tissue was measured 14 dai. For each seedling leaf, the 2-cm length of leaf tissue marked for colony number and percent sporulation measurements was cut. The leaf segments were placed in a petri dish on 3MM Whitman paper moistened with $\mathrm{ddH}_{2} \mathrm{O}$. The dishes were wrapped in aluminum foil and were left at $15^{\circ} \mathrm{C}$ for $24 \mathrm{~h}$. Spores were collected by tapping one leaf segment into an Eppendorf tube containing $200 \mu \mathrm{l}$ of sterile $\mathrm{ddH}_{2} \mathrm{O}$ plus $10 \mu \mathrm{l}$ of Tween 20 . Spores were counted using a haemocytometer, loading $20 \mu \mathrm{l}$ of spore suspension onto the slide. Four spore counts were taken for each leaf segment. Spore counts were calculated per square centimeter of inoculated leaf tissue. Spore counts for test 1 were taken from the fifth leaf and for test 2 from the eighth and ninth leaves.

\section{Genetic segregation analysis of yellow rust resistance.}

Mutants I3-48 and I3-54 (M10 generation) were crossed to Hobbit 'sib.' The $F_{2}$ and $F_{3}$ generations from these crosses were field tested for yellow rust resistance. Individual $\mathrm{F}_{2}$ plants were sown at a site near Norwich, U.K. in 2000 and were scored for yellow rust infection in June or July 2001. $F_{3}$ seed was collected from each $\mathrm{F}_{2}$ plant. $\mathrm{F}_{3}$ progeny rows (10 plants per row) were sown in two replicate plots in 2001 and 2002. The $\mathrm{F}_{2}$ and $\mathrm{F}_{3}$ generations were inoculated with $P$. striiformis $\mathrm{f}$. sp. tritici isolate WYR 79/4. The level of yellow rust infection was scored as a percentage of whole plant, green leaf tissue supporting spore production.

\section{Deletion segregation analysis of yellow rust resistance.}

$\mathrm{F}_{2}$ seedlings from the I3-48 $\times$ Hobbit 'sib' $\left(72 \mathrm{~F}_{2}\right.$ seedlings) and the I3-54 $\times$ Hobbit 'sib' (56 $\mathrm{F}_{2}$ seedlings) crosses were grown until the ninth and seventh leaves, respectively, had emerged. Seedlings were inoculated with the $P$. striiformis $\mathrm{f}$. sp. tritici isolate WYR79/4. The percentage of inoculated leaf tissue supporting sporulating yellow rust colonies was measured on the seventh and eighth leaves of the I3-48 $\times$ Hobbit 'sib' $F_{2}$ seedlings and on the fifth and sixth leaves of the I3-54 $\times$ Hobbit 'sib' $F_{2}$ seedlings.

All $F_{2}$ seedlings were grown until the twelfth leaf had emerged, and genomic DNA was extracted from clean, uninoculated leaf tissue, using the CTAB method (SaghaiMaroof et al. 1984). Along with genomic DNA from Hobbit 'sib', I3-48, and I3-54, the $\mathrm{F}_{2}$ DNA was cut with DraI or EcoRV. The I3-48 $\times$ Hobbit 'sib' $\mathrm{F}_{2}$ population was hybridized against the chromosome 4D RFLP probes, PSR104 and PSR163, and the I3-54 $\times$ Hobbit ' $s i b$ ' $F_{2}$ population was hybridized to the chromosome 7A RDA clones, RDA9 and RDA23 (Howie 1997; Smith et al. 2002).

\section{Statistical analysis.}

All statistical analysis was done using Genstat fifth edition for Windows. The levels of whole-plant yellow and brown rust infection were analyzed in each year by analysis of variance (ANOVA) and least significant difference (LSD). An angular transformation was carried out on the percent yellow rust and brown rust infection levels before performing ANOVA tests. Unless stated to the contrary, the cases discussed are those in which residuals were significant at an LSD $=0.1 \%$. For the seedling tests, levels of infection were analyzed using a general linear regression model. If the $\mathrm{F}$ value for isolates, lines, 
and leaf age were significant at the $0.1 \%(p<0.001)$ level, the differences between each sample for each infection character were tested by $t$-test, using the predicted means and standard errors of the frequencies. Chi-squared analysis was used to test for the number of mutation events segregating for yellow rust resistance in each mutant.

\section{Monosomic analysis.}

I3-48 and I3-54 were backcrossed to a complete series of Hobbit 'sib' monosomics. Each monosomic line is missing one chromosome of a pair, with the complete series consisting of 21 lines, one for each of the 21 pairs of chromosomes in hexaploid wheat. Three monosomic $F_{1}$ progeny were selected from each cross by determining chromosome numbers in root tip squash preparations (Miller and Chapman 1976). Selected $F_{1}$ plants were then selfed, and the segregating $F_{2}$ progeny and six $\mathrm{F}_{3}$ families of disomics identified at $\mathrm{F}_{2}$ were evaluated for yellow rust resistance in replicated field tests, inoculated with the P. striiformis f. sp tritici isolate WYR79/4.

\section{DNA marker analysis for uniformity.}

Genomic DNA was extracted using the CTAB method (Saghai-Maroof et al. 1984) from three, 14-day-old seedlings of Hobbit 'sib' and the mutant lines I3-48 and I3-54 (M11 generation) from cultivar Chinese Spring and from the Chinese Spring nullisomic and nulli-tetrasomic lines, which were used as controls to confirm the SSR marker pattern and chromosomal location. DNA polymorphism within and between the lines was examined using the wheat SSR markers of Bryan and associates (1997) and Roder and associates (1998). At least one SSR marker on each chromosome arm of the 21 chromosome pairs of hexaploid wheat was examined. The SSR analysis was performed as described by Bryan and associates (1997).

\section{RFLP screen for potential deletions.}

Genomic DNA from Hobbit 'sib,' I3-48, and I3-54 was cut with one of the following restriction enzymes, EcoRI, EcoRV, DraI, or HindIII. All RFLP techniques were as described by Smith and associates (2002). A total of 65 RFLP markers, consisting of cDNAs and single or low-copy-number gDNAs on chromosome groups 2 to 7 were used (Howie 1997). The RFLP screen was concentrated on chromosome groups 4 and 5 (24 and 17 RFLP markers, respectively), with fewer RFLP markers being screened on groups $2,3,6$, and $7(8,4,2$, and 10 RFLP markers, respectively).

\section{RDA screen for deletions.}

A genomic subtractive hybridization procedure based on RDA, as described by Lisitsyn and associates (1993), was used to extract deletion-specific clones for the mutant I3-54. Genomic DNA from Hobbit 'sib' and I3-54 was used as the tester and driver DNA, respectively (Howie 1997). The chromosomal location of isolated RDA clones was determined by hybridization of the RDA clones to the Chinese Spring nullisomic and nulli-tetrasomic series of wheat lines (Howie 1997; Sears 1954). Deletions of the RDA clones were detected as described for RFLP markers.

\section{ACKNOWLEDGMENTS}

This work was supported in part by Biotechnology and Biological Sciences Research Council grant D208/09472.

\section{LITERATURE CITED}

Aarts, N., Metz, M., Holub, E., Staskawicz, B. J., Daniels, M. J., and Parker, J. E. 1998. Different requirements for EDS1 and NDR1 by dis- ease resistance genes define at least two $R$ gene-mediated signaling pathways in Arabidopsis. Proc. Natl. Acad. Sci. U.S.A. 95:1030610311.

Assefa, S., and Fehrmann, H. 2000. Resistance to wheat leaf rust in Aegilops tauschii Coss. and inheritance of resistance in hexaploid wheat. Gen. Resour. Crop Evol. 47:135-140.

Bariana, H. S., and McIntosh, R. A. 1995. Genetics of adult plant stripe rust resistance in four Australian wheats and the French cultivar 'Hybride de Bersee.' Plant Breed. 114:485-491.

Bayles, R. A., Slater, S. E., and Hopkins, F. G. 2001. Yellow rust of wheat. Pages 28-35 in: The United Kingdom Cereals Pathogen Virulence Survey, Annual Report, National Institute of Agricultural Botany, Cambridge, U.K.

Boyd, L. A., and Minchin, P. N. 2001. Wheat mutants showing altered adult plant disease resistance. Euphytica 122:361-368.

Boyd, L. A., Smith, P. H., Green, R. M., and Brown, J. K. M. 1994. The relationship between the expression of defense-related genes and mildew development in barley. Mol. Plant-Microbe Interact. 7:41-49.

Boyd, L. A., Smith, P. H., Wilson, A. H., and Minchin, P. N. 2002. Mutations in wheat showing altered field resistance to yellow and brown rust. Genome 45:1035-1040.

Bryan, G. J., Collins, A. J., Stephenson, P., Orry, A., Smith, J. B., and Gale, M. D. 1997. Isolation and characterisation of microsatellites from hexaploid wheat. Theor. Appl. Genet. 4:557-563.

Century, K. S., Lagman, R. A., Adkisson, M., Morlan, J., Tobias, R., Schwartz, K., Smith, A., Love, J., Roland, P. C., and Whalen, M. C.

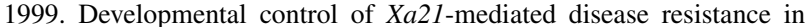
rice. Plant J. 20:231-236.

Clough, S. J., Fengler, K. A., Yu, L.-C., Lippok, B., Smith, R. K., and Bent, A. F. 2000. The Arabidopsis dnd1 "defense, no death" gene encodes a mutated cyclic nucleotide-gated ion channel. Proc. Natl. Acad. Sci. U.S.A. 97:9323-9328.

Gale, M. D., Atkinson, M. D., Chinoy, C. N., Harcourt, R. L., Jia, J., Li, Q. Y., and Devos, K. M. 1993. Genetic maps of hexaploid wheat, Pages 29-40 in: Proceedings of the 8th International Wheat Genetics Symposium. Vol. 1. China Agritech Publishing, Beijing, China.

Garrood, J. M. 2001. The interaction of Puccinia striiformis with wheat and barley. Ph.D. thesis, University of East Anglia, Norwich, U.K

Gray, J., Close, P. S., Briggs, S. P., and Johal, G. S. 1997. A novel suppressor of cell death in plants encoded by the Lls 1 gene in maize. Cell 89:25-31.

Howie, J. A. 1997. Adult plant resistance to fungal pathogens of wheat. $\mathrm{Ph} . \mathrm{D}$. thesis. Open University, London.

Jorgensen, J. H. 1992. Discovery, characterisation and exploitation of Mlo powdery mildew resistance in barley. Euphytica 63:141-152.

Kema, G. H. J., Lange, W., and van Silfhout, C. H. 1995. Differential suppression of stripe rust resistance in synthetic wheat hexaploids derived from Triticum turgidum subsp. dicoccides and Aegilops squarrosa. Phytopathology 85:425-429.

Kerber, E. R., and Aung, T. 1995. Confirmation of nonsupressor mutation of stem rust resistance in 'Canthatch' common wheat. Crop Sci. 35:743744

Kerber, E. R., and Aung, T. 1999. Leaf rust resistance gene Lr34 associated with nonsuppression of stem rust resistance in the wheat cultivar Canthatch. Phytopathology 89:518-521

Lisitsyn, L., Lisitsyn, N., and Wigler, M. 1993. Cloning the differences between two complex genomes. Science 259:946-951.

Ma, H., Singh, R. P., and Mujeeb-Kazi, A. 1995. Suppression/expression of resistance to stripe rust in synthetic hexaploid wheat (Triticum turgidum $\times$ T. tauschii). Euphytica 83:87-93.

McIntosh, R. A., and Arts, C. J. 1996. Genetic linkage of the Yr1 and Pm4 genes for stripe rust and powdery mildew resistance in wheat Euphytica 89:401-403.

McIntosh, R. A., Wellings, C. R., and Park R. F. 1995. Wheat Rusts: An Atlas of Resistance Genes. Kluwer Academic Publishers, Dordrecht, The Netherlands.

Miller, T. E., and Chapman, V. 1976. Aneuploids in bread wheat. Genet. Res. 28:37-45.

Nelson, J. C., Singh, R. P., Autrique, J. E., and Sorrells, M. E. 1997. Mapping genes conferring and suppressing leaf rust resistance in wheat. Crop Sci. 37:1928-1935.

Piffanelli, P., Zhou, F., Casais, C., Orme, J., Jarosch, B., Schaffrath, U. Collins, N. C., Panstruga, R., and Schulze-Lefert, P. 2002. The barley MLO modulator of defence and cell death in response to biotic and abiotic stress stimuli. Plant Physiol. 129:1076-1085.

Pink, D. A. C., Bennett, F. G. A., Caten, C. E., and Law, C. N. 1983. Correlated effects of homoeologous group 5 chromosomes upon infection of wheat by yellow rust and powdery mildew. Z. Pflanzenzuchtg 91:278-294. 
Roder, M. S., Korzun, V., Wendehake, K., Plaschke, J., Tixier, M-H., Leroy, P., and Ganal, M. W. 1998. A microsatellite map of wheat. Genetics 149:2007-2023.

Saghai-Maroof, M. A., Soliman, K. M., Jorgensen, R. A., and Allard, R. W. 1984. Ribosomal DNA spacer length polymorphisms in barley: Mendelian inheritance, chromosomal location and population dynamics. Proc. Natl. Acad. Sci. U.S.A. 81:8014-8018.

Sears, E. R. 1954. The aneuploids of common wheat. Page 59 in: Missouri Agricultural Experimental Station Research Bulletin 572, Columbia, MO, U.S.A.

Simmons, C., Hantke, S., Grant, S., Johal, G. S., and Briggs, S. P. 1998 The maize lethal leaf spot 1 mutant has elevated resistance to fungal infection at the leaf epidermis. Mol. Plant-Microbe Interact. 11:11101118.

Singh, R. P. 1993. Genetic association of gene $B d v 1$ for tolerance to barley yellow dwarf virus with genes $\operatorname{Lr} 34$ and $\mathrm{Yr} 18$ for adult plant resistance to rusts in bread wheat. Plant Dis. 77:1103-1106.

Singh, R. P., Huerta-Espino J., and William, M. 2001. Slow rusting gene based resistance to leaf and yellow rust in wheat: Genetics and breeding at CIMMYT. Pages 103-108 in: 10th Assembly Proceedings, Wheat Breeding Society of Australia. Mildura, Australia.
Smith, P. H., Koebner, R. D. M., and Boyd, L. A. 2002. The development of a STS marker linked to a yellow rust resistance derived from the wheat cultivar Moro. Theor. Appl. Genet. 104:1278-1282.

Takahashi, A., Kawasaki, T., Henmi, K., Shii, K., Kodama, O., Satoh, H., and Shimantoo, K. 1999. Lesion mimic mutants of rice with alterations in early signaling events of defence. Plant J. 17:535-545.

Vogel, J. P., Raab, T. K., Schiff, C., and Somerville, S. C. 2002. PMR6, a pectate-lyase-like gene required for powdery mildew susceptibility in Arabidopsis. Plant Cell 14:2095-2106.

Wilson, W. A., and McMullen, M. S. 1997. Dosage dependent genetic suppression of oat crown rust resistance gene Pc-62. Crop Sci. 37:16991705 .

Worland, T., and Law, C. 1992. Improving disease resistance in wheat by inactivating genes promoting disease susceptibility. Mutat. Breed. Newsl. 38:2-5

Zadoks, J. C., Chang, T. T., and Konzak, C. F. 1974. A decimal code for the growth stages of cereals. Weed Res. 14:415-421.

Zeng, L., Yin, Z., Chen, J., Leung, H., and Wang, G. L. 2002. Fine genetic mapping and physical delimination of the lesion mimic gene Spl11 to a $160 \mathrm{~kb}$ DNA segment of the rice genome. Mol. Genet. Genomics 268:253-261. 